\title{
Sustainable Development and SDG-7 in Sub-Saharan Africa: Balancing Energy Access, Economic Growth, and Carbon Emissions
}

\author{
Dmitriy $\mathrm{Li}^{1}$ · Jeong Hwan Bae ${ }^{1} \cdot$ Meenakshi Rishi ${ }^{2}$
}

Accepted: 29 November 2021 / Published online: 28 January 2022

(c) European Association of Development Research and Training Institutes (EADI) 2022

\begin{abstract}
The Covid-19 pandemic has shocked the global energy system. It has resulted in tremendous uncertainty and diminished the recent advances to increase access to affordable, reliable, sustainable and modern energy — an objective preserved in the UN Sustainable Development Goal 7 (SDG-7). According to the IEA, attaining universal electricity access in Africa in line with SDG-7 entails annual investments of approximately $\$ 20$ billion over the next decade. Given the sizeable magnitudes involved, it is inevitable that energy projects will need to rely on richer nations for energy aid. This paper explores the linkages between energy-related external aid, carbon emissions, per capita GDP, and electricity access for a sample of 30 lowincome SSA countries over 1995 to 2016. Our econometric analysis reveals that while all types of energy aid facilitate economic growth in the long run, there is no direct impact of energy-related aid on electricity access. However, an increase in per capita GDP is positively associated with electricity access in both rural and urban areas. We also find that energy-related aid helps mitigate carbon emissions as well as contribute to GDP. Taken together, our results suggest that enhanced energyrelated aid to low-income SSA countries can directly facilitate climate compatible growth and indirectly impel improvements in electricity access thereby helping with poverty reduction. We also advocate regional cooperation among SSA countries as a collective effort to confront shared energy challenges.
\end{abstract}

Keywords Energy-related aid · Electricity access · Economic growth $\cdot \mathrm{CO}_{2}$ emissions $\cdot$ Sub-Saharan African countries

Meenakshi Rishi

rishim@seattleu.edu

1 Department of Economics, Chonnam National University, Gwangju, South Korea

2 Department of Economics, Seattle University, Seattle, USA 


\section{Résumé}

La pandémie de Covid-19 a bouleversé le système énergétique mondial. Cela a entraîné une très grande incertitude et a fait reculer les progrès réalisés récemment pour accroître l'accès à une énergie abordable, fiable, durable et moderne-un objectif qui fait partie de l'Objectif de développement durable 7 (ODD 7) des Nations Unies. Selon l'AIE, pour atteindre l'accès universel à l'électricité en Afrique, conformément à l'ODD 7, il faut des investissements annuels d'environ 20 milliards de dollars au cours de la prochaine décennie. Compte tenu de l'ampleur considérable de ce qui est en jeu, il est inévitable que les projets énergétiques aient besoin de s'appuyer sur les pays les plus riches pour obtenir une aide énergétique. Cet article explore les liens entre l'aide extérieure liée à l'énergie, les émissions de carbone, le PIB par habitant et l'accès à l'électricité, sur un échantillon de 30 pays à faible revenu d'Afrique subsaharienne de 1995 à 2016. Notre analyse économétrique révèle que même si tous les types d'aide énergétique contribuent à la croissance à long terme, il n'y a pas d'impact direct des aides liées à l'énergie sur l'accès à l'électricité. Cependant, il existe un lien entre l'augmentation du PIB par habitant et l'accès à l'électricité dans les zones rurales et urbaines. Nous constatons également que l'aide liée à l'énergie permet d'atténuer les émissions de carbone et contribue au PIB. Lorsqu'on les considère dans leur globalité, nos résultats suggèrent qu'une aide énergétique accrue auprès des pays à faible revenu d'Afrique subsaharienne peut directement faciliter une croissance respectueuse du climat et favoriser indirectement l'amélioration de l'accès à l'électricité, contribuant ainsi à la réduction de la pauvreté. Nous préconisons également la coopération régionale entre les pays d'Afrique sub-saharienne en tant qu'effort collectif pour relever des défis énergétiques communs.

JEL Codes $\mathrm{C} 13 \cdot \mathrm{O} 44 \cdot \mathrm{P} 45 \cdot \mathrm{O} 55 \cdot \mathrm{Q} 50$

\section{Introduction}

Access to clean energy is vital to the functioning of a sustainable planet. Policymakers believe that universal access to affordable, reliable, and clean energy can help eradicate poverty, improve health, achieve gender equality, and enable communities to adapt to climate change and food security issues (Modi et al. 2005; Legros et al. 2009). Clean and reliable energy can generate jobs, improve transportation, and help create more sustainable, inclusive, and resilient communities. Accordingly, the provision of affordable and clean energy is one of the 17 global goals adopted by the United Nations General Assembly in 2015. ${ }^{1}$ Yet, the World Bank (2019) estimates that 840 million people still live without electricity and the Sub-Saharan Africa is home to three-fourths of them. The Covid-19 pandemic has led to an increased immiseration of this population and a recent report indicates that the number of

\footnotetext{
1 United Nations, 2015, 'Transforming our world: the 2030 Agenda for Sustainable Development'. https://www.iea.org/articles/the-covid-19-crisis-is-reversing-progress-on-energy-access-in-africa.
} 
people without access to electricity in sub-Saharan Africa rose by $2 \%$ in 2020 compared to the pre-pandemic level (IEA 2020a, b).

Several countries in Africa were making good progress on improving electricity access in the last decade. Since 2013, Kenya, Senegal, Rwanda and Ghana had adopted strong electricity access policies and enhanced support for off-grid initiatives. The pandemic has upended these gains and derailed plans to reach universal energy access by 2030. This reversal of progress stems mainly from a lack of available financial resources. Covid-19 has also forced states to reallocate priorities, resulting in a lack of financing available for expanding and improving electricity access. Many private companies deploying decentralized energy solutions like solar home systems and mini-grids have also faced operational and financial challenges because of the pandemic. Although a few markets like Kenya, Rwanda and Togo have remained strong, sales of solar products in SSA have dropped by more than 10 percent in the first half of 2020. These trends imply that many households in the region do not have access to basic electricity services. For the SSA, the IEA (2020a, b) estimates that in the first half of 2020 , sovereign risks perceived by investors (i.e., the premium on top of the long-term cost of borrowing) rose by two percentage points compared to the end of 2019. Rising financing costs have crimped progress on expanding electricity access.

In order to meet the objectives of SDG-7 and attain universal electricity access, the SSA region will require around \$20 billion of annual investments over the next decade (IEA 2020a, b). This will be a challenging goal as the current investment in the region's power system is only around 8 billion US\$ per year (Hafner et al. 2018). This significant gap in the energy investment in the SSA region underscores the vital need to mobilize development finance institutions and donors. To add to the complexity facing policymakers, energy-related aid, while necessary for economic growth can also be associated with increased carbon emissions. The burning of fossil fuels for energy in the SSA region accounts for $36 \%$ of total greenhouse gas emissions. $^{2}$

Discussions on energy aid for the SSA region have understandably focused on the tradeoffs between economic growth and environmental quality. Several studies have previously noted the association between economic growth, energy, and environmental pollution (Bekhet et al. 2017; Nazeer et al. 2016; Asumadu-Sarkodie and Owusu 2016). Traditionally, energy aid for development has targeted two separate goals: economic growth or poverty reduction while policy prescriptions attempt to address obstacles of growth, poverty, mitigation and adaptation for climate change simultaneously. A reality check suggests that this multiplicity of objectives has not been very successful. Higher economic growth is associated with increased emissions as fossil fuels are cheaper and less capital intensive than renewable energy options. Bruggink (2012) argues that environmental problems stemming from higher economic growth are very different from those pertaining to persistent poverty (energy access and adaptation). Bruggink (2012) suggests that energy aid discussion should be reframed to find solutions in two integrated but separate spaces-viz.

${ }^{2}$ CAIT Climate Data Explorer, FAOSTAT emissions database. 
Fig. 1 Energy aid, economic growth, carbon emissions and electricity access-a schematic representation

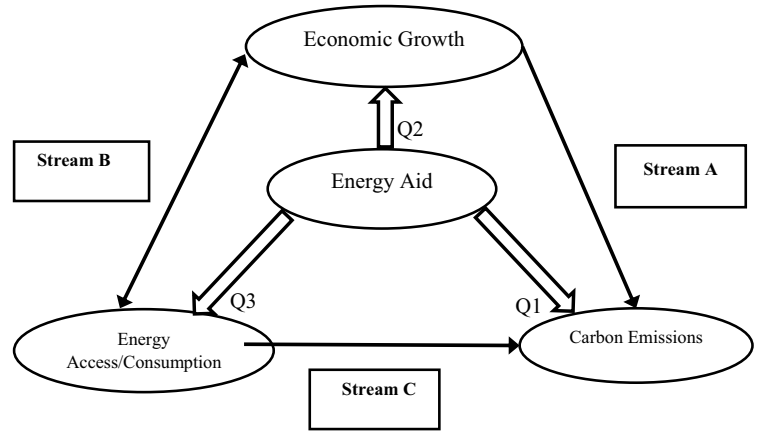

green growth and energy access rather than as anerlapping mix of development, mitigation, and adaptation strategies could help in designing effective development strategies.

The main objective of this paper is to empirically test Bruggink's (2012) reframed theory on climate compatible development strategies to explore three research questions for a sample of 30 SSA countries over 1995-2016 (Q1-Q3). ${ }^{3}$ First, is increased energy aid associated with mitigated carbon emissions (Q1)? Second, does energy aid promote economic growth (Q2)? And lastly, does energy aid improve access to energy (Q3)? There is only scant literature on assessing the impact of energy-related aid on carbon emissions. Bhattacharyya et al. (2016) employed global data to demonstrate an insignificant effect of energy aid on emissions. But the results of this ambitious study may suffer from bias due to heterogeneity across panels. Our paper only considers low-income SSA countries, ${ }^{4}$ thereby reducing the possibility of heterogeneity bias. Another novelty of our study is that it employs electricity access as an energy variable, while other studies mostly use energy or electricity consumption.

\section{Literature Review}

For ease of exposition, we have consolidated relevant literature on growth, carbon emissions and energy access into three main streams as illustrated in Fig. 1.

Literature Stream A Several studies have focused attention on the relationship between economic growth and carbon emissions (environment). These studies are closely related to testing the validity of the environmental Kuznets curve (EKC). The EKC hypothesis was initially proposed and tested by Grossman and Krueger (1991), who postulated an inverted U-shaped relationship between per capita income and environmental degradation. Empirical evidence on the existence of the EKC hypothesis is mixed (see Mehdi and Youssef 2015; Liobikienè and Butkus 2017; Hu et al.

\footnotetext{
3 The choice of our time-period is guided by data limitations. World bank data on carbon emissions for our sample are available only up to 2016.

4 This paper uses World Bank country classifications by income level, which is based on GNI per capita in current USD (using the Atlas method exchange rates) in 1995 (beginning of analyzed period).
} 
2018; Marques et al. 2018). Using different estimation methods, some studies have found an inverse U-shaped relationship between $\mathrm{CO}_{2}$ emissions and GDP (Galeotti and Lanza 1999; Esteve and Tamarit 2012). Others have noted an N-shaped relationship between $\mathrm{CO}_{2}$ emissions and economic growth (Friedl and Getzner 2003; Martınez-Zarzoso and Bengochea-Morancho 2004) and some have concluded that $\mathrm{CO}_{2}$ emissions and GDP are positively correlated (Shafik 1994; Lipford and Yandle 2010).

The EKC hypothesis has also been criticized for some drawbacks relating to econometric issues such as unit root, cointegration, and the causality between environmental indicators and GDP levels (Chow and Li 2014). Consequently, recent studies on the income-pollution relationship have more focused on long-run causality (Dinda and Coondoo 2006; Lee and Lee 2009; Hossain 2011; Odhiambo 2012; Chen and Huang 2013) and non-linearity between per capita GDP and $\mathrm{CO}_{2}$ emissions (Chiu 2017). Many EKC studies note that developing countries do not display EKC relations and carbon emissions increase with economic growth (Alam et al. 2016; Alshehry and Belloumi 2015). The increase in the carbon emissions with economic growth results from globalization in developing countries, weak environmental policies and low energy efficiency.

Literature Stream B A second line of research focuses on the relationship between economic growth and energy consumption. In general, studies find evidence of correlation between growth and energy consumption for countries with different economic structures and at different stages of economic development. Ozturk (2010) has reviewed more than 100 relevant studies for a wide range of countries, and concluded that empirical results are inconclusive in terms of the existence and direction of causality between the two variables. The relationship between electricity consumption and economic growth can be unidirectional-which means that electricity consumption can stimulate economic growth (Altinay and Karagol 2005). The relationship can also run from economic growth to electricity consumption (Narayan et al. 2008). Kraft and Kraft (1978) applied Granger causality tests to U.S. data for the period of 1947-1974, and noted a unidirectional causality from economic growth to energy consumption, thus implying that an energy conservation policy is feasible. There may also be a bidirectional causal relationship between electricity consumption and economic growth. For example, Srivastava (2016) and Bayar and Özel (2014) have used a panel data analysis to show a bidirectional relationship between energy consumption and economic growth in India.

These studies on economic growth and energy consumption notwithstanding, there are only scant literature on the association between economic growth and energy access. As mentioned, access to energy is a basic ingredient for development and is significantly associated with poverty reduction via productivity, income growth, health and education, gender, social impacts of energy extraction, human development, and via macroeconomic stability and governance (World Bank 2001). Only a few empirical studies have examined the impact of electricity access on poverty reduction (Balisacan 2001; Fan et al. 2000, 2002); on productivity (Barnes and Binswanger 1986; Escribano et al. 2009); on employment (Kooijman-van Dijk 2008, 2012; Goedhuys and Sleuwaegen 2010; Dinkelman 2008) and on household income (Grimm et al. 2011; Fan et al. 2005; ESMAP 2005). 
Literature Stream $C$ Literature that focuses on the relationship between $\mathrm{CO}_{2}$ emissions and electricity access is very limited. Tait and Winkler (2012) estimated electricity demand and carbon emissions for the residential sector in 2020, operating under a theoretical scenario of universal access in South Africa. Their results indicated that total household emissions would grow from $41 \mathrm{Mt} \mathrm{CO}_{2}$ in 2006 to 54 $\mathrm{Mt} \mathrm{CO}_{2}$ in 2020 if $100 \%$ of existing households were electrified. The authors note that emissions associated with this increased access to electricity for low-income households would not contribute significantly to total $\mathrm{CO}_{2}$ emissions. Chakravarty and Tavoni (2013) also note that an energy poverty eradication policy goal of 2030 would have a very small impact on global energy consumption. The IEA asserts that additional electricity consumed by the newly connected households (alongside the gas used in clean cooking) would add just $0.7 \%$ to global $\mathrm{CO}_{2}$ emissions in 2030. This is because energy access would add just $1.1 \%$ to global energy demand. ${ }^{5}$

Where the impact of aid is concerned, our exhaustive review of the literature reveals that most studies examine either the relationship between total aid and economic growth ${ }^{6}$ or the impact of total aid on the environment. For instance, Chao and $\mathrm{Yu}$ (1999) suggest gains from environmental cleanup attributable to tied aid would be beneficial for both donor and recipient countries. In a two-country model, Hatzipanayotou et al. (2002) demonstrate that aid could lead to reductions in the total amount of emissions because of the medium and longer-term impact of crossborder pollution. Arvin et al. (2006) utilized Granger causality tests to show that aid reduces emissions in low-income countries but increases emissions in higher income countries. Arvin and Lew (2009) note that aid helps reduce $\mathrm{CO}_{2}$ damage but increases water pollution and deforestation. Mahalik et al. (2021) have also explored the association between carbon emissions and total and energy-related aid in India. The authors utilized an ARDL bound test to note that while total aid reduces emissions, energy-related aid is associated with increased emissions in India.

An exhaustive examination of the literature indicates a paucity of scholarly work that examines the impact of energy-related aid on economic growth and carbon emissions- viz., the above-mentioned green growth initiative. Further, literature has not paid attention to the impact of energy-related aid on energy access. As emphasized in Bruggink (2012) energy access specifically captures the effect of energyrelated aid on poverty reduction. By exploring the linkage between energy-related aid, economic growth, and energy access our study will attempt to reframe the conversations about the efficacy of energy-related aid. As Bruggink (2012) highlights, a reframed analysis that centers the divide between green growth and energy access rather than the traditional scholarly split between economic development and climate change is more germane to the needs of developing economies.

\footnotetext{
5 https://www.motherjones.com/environment/2015/10/electricity-poverty-united-nations-sustainabledevelopment/.

${ }^{6}$ The debate on the relationship between foreign aid and economic growth is ongoing. Many studies suggest that aid works, but only when policies are right (World Bank 1998; Burnside and Dollar 1997; Collier and Dollar 2001, 2002; Dalgaard and Hansen 2001; Hansen and Tarp 2001; Lensink and White 2001; Jensen and Paldam 2003; Islam 2002; Ram 2004).
} 


\section{Theory, Data and Methodology}

\section{Theoretical Framework}

To estimate the impact of energy-related aid on $\mathrm{CO}_{2}$ emissions, GDP, and electricity access and its long-run and the short-run relationship we set up a dynamic panel approach, which is based on an autoregressive distributed lag (ARDL) model.

Given the following $\operatorname{ARDL}\left(p, q_{1}, \ldots, q_{k}\right)$ model:

$$
y_{i t}=\sum_{j=1}^{p} \lambda_{i j} y_{i, t-j}+\sum_{j=0}^{q} \delta_{i j}^{\prime} x_{i, t-j}+\mu_{i}+\varepsilon_{i t}
$$

where the number of periods $t=1 \ldots T$, the number of countries $i=1 \ldots N, y_{i t}$ dependent variable, $x_{i t}(k \times 1)$ is the vector of explanatory variables, $\mu_{i}$ is the group-specific effect, $\lambda_{i t}$ are scalars, $\delta_{i t}$ are $k \times 1$ coefficient vector, $p$ is a maximum lag for dependent variable and $q$ is a maximum lag for $k$ th explanatory variable.

Taking the differences of Eq. (1) and rearranging terms yield the vector error correction model:

$$
\Delta y_{i t}=\sum_{j=1}^{p-1} \lambda_{i j}^{*} \Delta y_{i, t-j}+\sum_{j=0}^{q-1} \delta_{i j}^{\prime *} \Delta x_{i, t-j}+\varphi_{i}\left[y_{i t-1}-\theta_{i}^{\prime} x_{i t}\right]+\mu_{i}+\varepsilon_{i t}
$$

where

$$
\theta_{i}=\frac{\sum_{j=0}^{q} \delta_{i t}}{1-\sum_{k} \lambda_{i k}}, \varphi_{i}=-\left(1-\sum_{j=1}^{p} \lambda_{i j}\right)
$$

$\lambda_{i j}^{*}=-\sum_{m=j+1}^{p} \lambda_{i m}, j=1,2, \ldots, p-1$ and $\delta_{i j}^{\prime *}=-\sum_{m=j+1}^{q} \delta_{i m}, j=1,2, \ldots, q-1$.

The parameter $\varphi_{i}$ in Eq. (2) is the error correction term and reflects the speed of adjustment to the long-run equilibrium. For the existence of the long-run relationship between variables, $\varphi_{i}$ should be negative and statistically significant, otherwise, there would be no evidence for the long-run equilibrium. The vector $\theta_{i}$ contains the long-run relationships between variables and $\delta_{i}^{*}$ is a vector of shortrun relationships coefficients.

To investigate the relationship between $\mathrm{CO}_{2}$ emissions, GDP, electricity access and energy-related aid, we implemented a pooled mean group (PMG) estimator, proposed by Pesaran et al. (1999) which is based on maximum likelihood estimation (MLE). This procedure is widely used for a large group (N) and large time series observations (T) panels. It allows short-run coefficients, the intercept, and the error variance to be heterogeneous across panels while long-run coefficients are constrained to be equal across panels. When the $\mathrm{N}$ is rather small, as is the case with our study, a PMG estimator can simultaneously correct the serial autocorrelation problem and the problem of endogenous and non-stationary regressors by selecting an appropriate lag structure for both dependent and independent variables. Fayad (2010) and Salim et al. (2014) note that the PMG estimator is also robust to the choice of lag orders. 
For our study, our choice of lag order was based on the Schwarz criterion (SC) and Hannan-Quinn criterion (HQ) subject to a maximum lag of three, due to the relatively short time period (22 years). Based on the SC and HQ criterion results, an $\operatorname{ARDL}(1,1,1,1)$ model emerges as the preferred option for all models and equations. Thus, we set the maximum lag as one and estimated the following error correction equations:

$$
\begin{aligned}
& \Delta \mathrm{CO}_{2 i t}=\varphi_{i}^{\mathrm{CO}_{2}}\left(\mathrm{CO}_{2 i t-1}-\theta_{0 i}^{\mathrm{CO}_{2}}-\theta_{1 i}^{\mathrm{CO}_{2}} \mathrm{GDP}_{i t}-\theta_{2 i}^{\mathrm{CO}_{2}} \mathrm{EA}_{i t}^{T}-\theta_{3 i}^{\mathrm{CO}_{2}} \mathrm{AID}_{i t}\right) \\
& +\delta_{11 i}^{\mathrm{CO}_{2}} \Delta \mathrm{GDP}_{i t}+\delta_{21 i}^{\mathrm{CO}_{2}} \Delta \mathrm{EA}_{i t}^{T}+\delta_{31 i}^{\mathrm{CO}_{2}} \mathrm{AID}_{i t}+\varepsilon_{i t}^{\mathrm{CO}_{2}} \\
& \Delta \mathrm{GDP}_{i t}=\varphi_{i}^{\mathrm{GDP}}\left(\mathrm{GDP}_{i t-1}-\theta_{0 i}^{\mathrm{GDP}}-\theta_{1 i}^{\mathrm{GDP}} \mathrm{CO}_{2 i t}-\theta_{2 i}^{\mathrm{GDP}} \mathrm{EA}_{i t}^{\mathrm{T}}-\theta_{3 i}^{\mathrm{GDP}} \mathrm{AID}_{i t}\right) \\
& -\delta_{11 i}^{\mathrm{GDP}} \Delta \mathrm{CO}_{2 i t}-\delta_{21 i}^{\mathrm{GDP}} \Delta \mathrm{EA}_{i t}^{\mathrm{T}}-\delta_{31 i}^{\mathrm{GDP}} \mathrm{AID}_{i t}+\varepsilon_{i t}^{\mathrm{GDP}}
\end{aligned}
$$

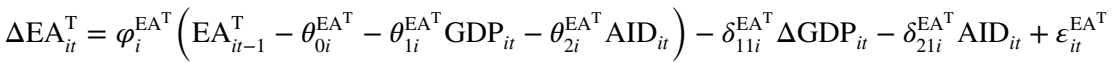

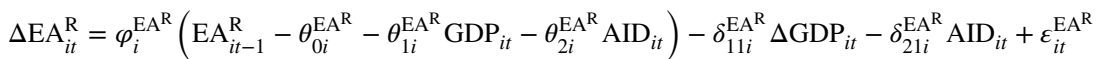

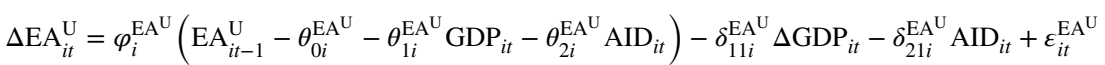

$$
\mathrm{AID}=\mathrm{ERA} \text { or REA and EDA. }
$$

In Eqs. (3)-(7), GDP refers to per capita GDP in constant 2010 US\$, per capita; $\mathrm{CO} 2$ is carbon emissions in metric kilos. $\mathrm{EA}^{\mathrm{T}}$ stands for total electricity access and is calculated as the percentage of the population with access to electricity. Rural electricity access $\left(\mathrm{EA}^{\mathrm{R}}\right)$ and urban electricity access $\left(\mathrm{EA}^{\mathrm{U}}\right)$ are the percentage of the population with access to electricity in rural and urban areas, respectively. Total energy-related aid (ERA) comprises of tied aid for energy policy, energy generation from nuclear, hybrid, renewable, non-renewable sources and aid for electricity transmission and distribution. Renewable energy aid (REA) includes aid for hydroelectric power plants, biofuel power plants, solar, wind, marine and geothermal energy. Energy distribution aid (EDA) incorporates aid targeted on heat plants, electric power transmission and distribution, distinct heat, and cooling \& electric mobility infrastructure. The variable AID captures energy-related aid (ERA) or renewable energy aid (REA) and energy distribution aid (EDA) as illustrated above. Note that in Eqs. (5-7) with electricity access as dependent variable, the $\mathrm{CO}_{2}$ variable is omitted, as there is no theoretical association between emissions and access to electricity. We use each of the above Eqs. (3-7) for estimation of two distinct specifications by substituting the AID 
variable with either total energy-related aid (ERA) or with renewable energy aid (REA) and energy distribution aid (EDA).

The PMG estimator allows for testing long-run relationships between variables with mixed orders of integration, provided that the dependent variable is constrained to be integrated in order one-I(1). Thus, the applications of PMG estimates do not require cointegration tests. However, the PMG estimator cannot be utilized when the series are integrated in order $2-I(2)$ or higher. Therefore, before the estimation of long-run and short-run relationships, we test the integration order of our variables via panel unit root tests.

From Eq. (2), recall that the parameter $\varphi_{i}$ refers to error correction term and reflects the speed of adjustment to the long-run equilibrium. A negative and significant $\varphi_{i}$ indicates the existence of a long-run relationship between variables. The vector $\theta_{i}$ contains the long-run relationships between variables. Thus, we can test long-run relationships by examining a null hypothesis $\mathrm{H} 0: \varphi_{i}=0$ and testing the significance of long-run coefficients $\theta_{i}$. For example, in Eq. (4), the existence of long-run relationship of $\mathrm{CO}_{2}$ emissions on GDP can be expressed as $\varphi_{i}^{\mathrm{GDP}} \neq 0$ and $\theta_{1 i}^{\mathrm{GDP}} \neq 0$.

$\delta_{i}^{*}$ is a vector of short-run relationships coefficients. The short-run relationships are examined by estimating the coefficients of variables in first difference. For example, in Eq. (4) the short-run causality from $\mathrm{CO}_{2}$ emissions to GDP is tested for no causality $\left(H_{0}: \delta_{11 i}^{\mathrm{GDP}}=0\right)$. Thus, the long-run coefficients in the ARDL model are expressed in levels, while short-run coefficients are expressed in difference. The PMG estimator allows for testing long-run relationships between variables with mixed orders of integration, provided that the dependent variable is constrained to be integrated in order one-I(1). Thus, the applications of PMG estimates do not require cointegration tests. However, the PMG estimator cannot be utilized when the series are integrated in order $2-I(2)$ or higher. Therefore, before the estimation of long-run and short-run relationships, we test the integration order of our variables via panel unit root tests.

\section{Data}

Our empirical investigation will focus on a sample of 30 low-income SSA countries over a twenty two-year period from 1995 to 2016. Although the data for most variables considered in this paper available for later periods, the data for carbon emissions (CO2) is only available up to 2016. GDP and electricity access data (EA) are obtained from the World Bank World Development Indicators (WDI 2021). To reduce the scale effect of the $G D P, C O 2$ and electricity access variables we use a natural logarithm transformation. Data on energy-related aid was obtained from the Creditor Reporting System (CRS) (http://stats.oecd.org) and measured in constant 2018 US\$. To reduce the scale effect of aid variables, we utilize the ratio of energy aid to real GDP in our estimations. 
Fig. 2 Rural electricity access for SSA countries

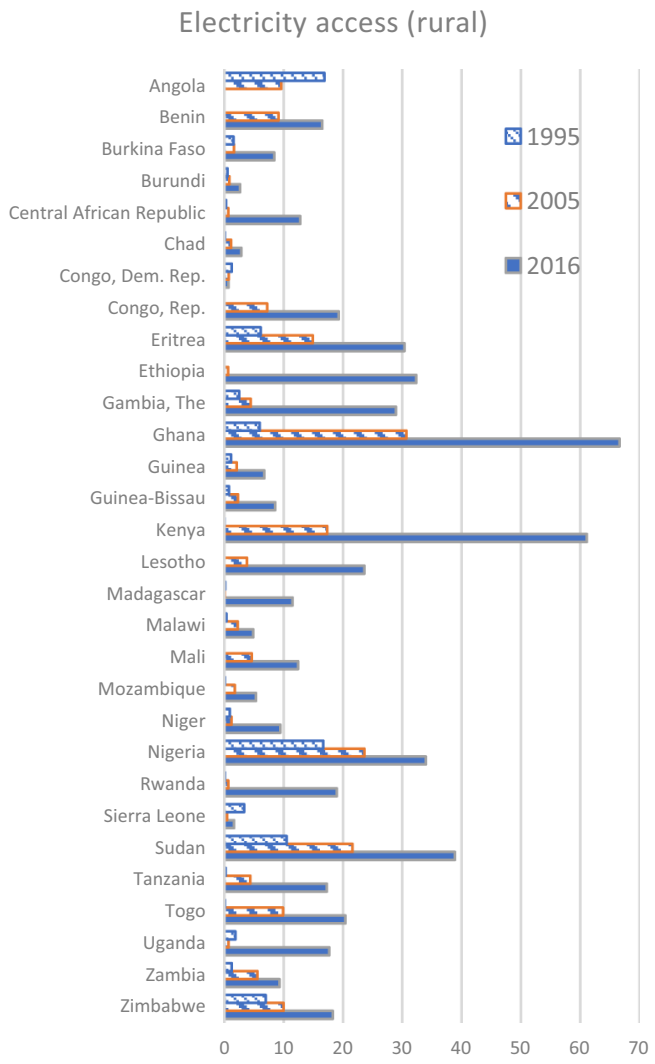

Descriptive statistics and country list are contained in the Appendix (Tables 6 and 7). Figures 2 and 3 compare rural and urban access to electricity for 1995, 2005 and 2016 for the countries in our sample. Although there has been some progress in access to electricity during the last decade, in 2016, electricity access in rural areas was below $10 \%$ in 11 out of the 30 SSA countries within our sample. ${ }^{7}$ The situation in urban areas is better than that in rural areas, but some countries still suffer from low electricity access even in urban areas. For instance, in eight low-income SSA countries $^{8}$ electricity access in 2016 in urban areas still was below 60\%. Figure 4 indicates that only 10 of 30 SSA countries in our sample have a greater than $40 \%$ total electricity access in 2016.

\footnotetext{
${ }^{7}$ Democratic Republic of Congo, Sierra Leone, Chad, Burundi, Burkina Faso, Guinea, Guinea-Bissau, Malawi, Niger, Mozambique, Zambia.

${ }^{8}$ Burundi, Chad, Central African Republic, Guinea-Bissau, Democratic Republic of Congo, Malawi, Sierra Leone, and Uganda.
} 
Fig. 3 Urban electricity access for SSA countries

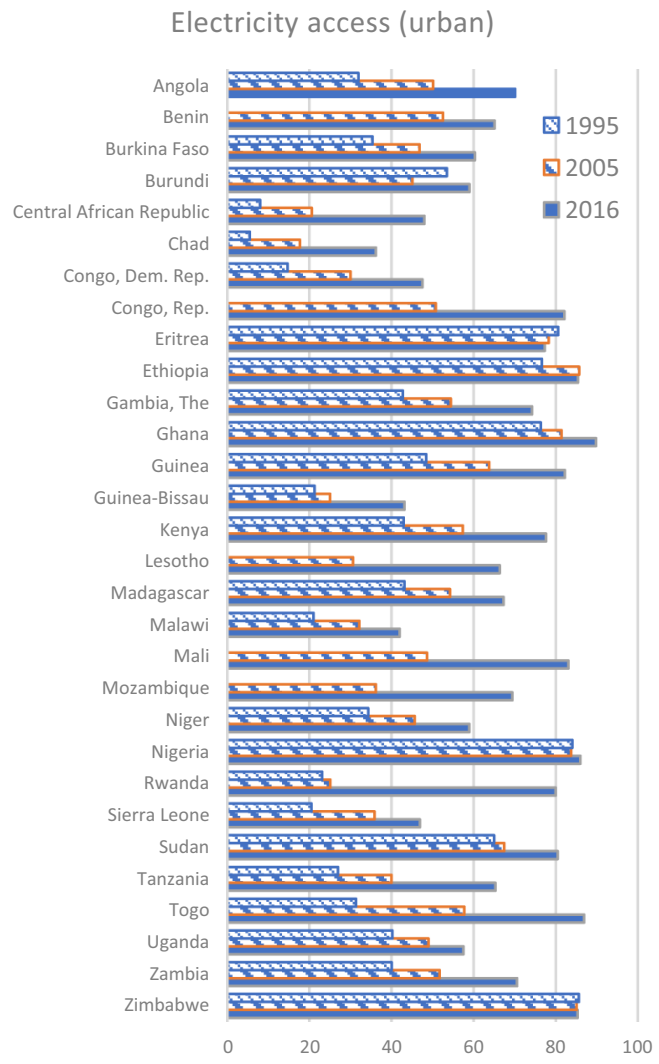

\section{Estimation Results}

As discussed above, the PMG estimator cannot be applied when the series are integrated of order $2-(I(2))$ or higher. Hence, before estimating dynamic panel models, we conducted panel unit root tests. ${ }^{9}$

Results in Table 1 indicate that the level values for $\mathrm{CO}_{2}$ emissions, GDP and rural electricity access are not stationary, but the series are stationary for the first difference at the $1 \%$ significance level suggesting that these variables are integrated in order $1-I(1)$. Based on IPS, ADF-Fisher and Hadri panel unit root tests, the log of total and urban electricity access are also $I(1)$ variables, but an LLC unit ${ }^{10}$ root

\footnotetext{
${ }_{9}^{9}$ Our panel unit root tests are based on Levin, Lin, Chu (LLC 2002), Im, Pesaran and Shin (IPS 2003), ADF-Fisher (Maddala and Wu 1999) and Hadri (2000). According to Al Mamun (2013), IPS (2003) tests are the most efficient for investigating the presence of unit roots when number of panels and periods are small. But, according to Baltagi (2005), the presence of a linear time trend decreases the power of all first-generation unit root tests considerably. Therefore, we do not include panel unit root test results with linear time trend. For LLC (2002), ADF-Fisher, and IPS (2003), the null hypothesis is that panels contain unit roots versus the alternative that panels are stationary. For Hadri (2000) panel unit root test, the null is that all panels are stationary.

${ }^{10}$ Levin, Lin, Chu (LLC 2002), Im, Pesaran and Shin (IPS 2003), ADF-Fisher (Maddala and Wu 1999), and Hadri (2000).
} 
Fig. 4 Total electricity access for SSA countries

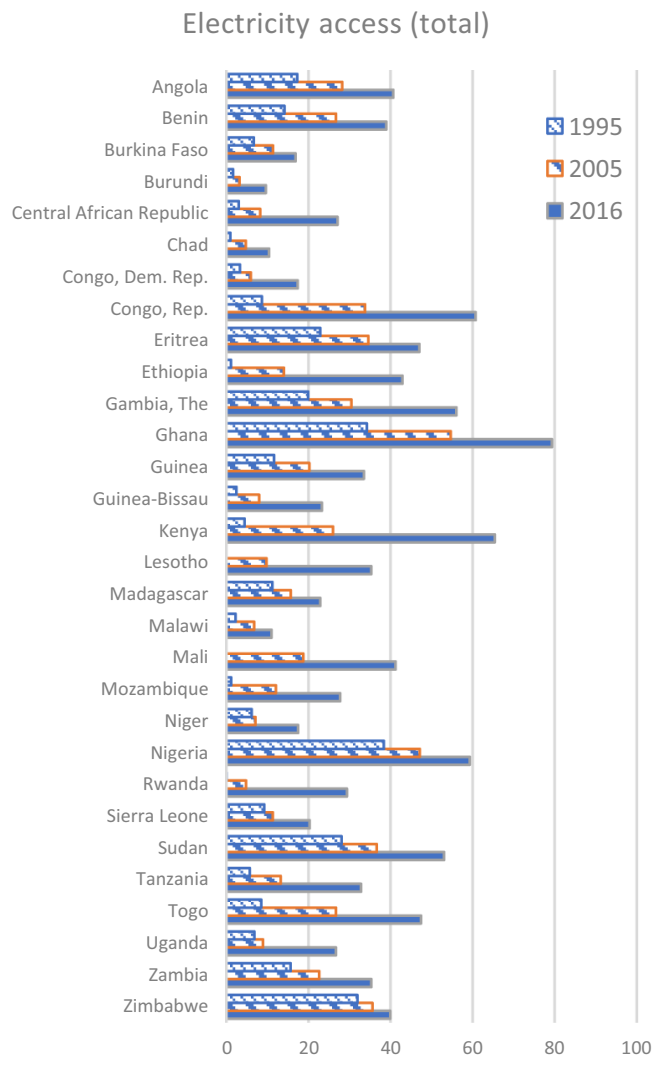

test suggests that these access variables are stationary in levels. This is suggestive of inconsistencies that may occur because an LLC test assumes a common unit root process. Total energy-related aid, renewable energy aid, and distribution energy aid are found to be stationary at levels, based on LLC, IPS, ADF-Fisher test, but not under Hadri test, which also assumes a common unit root process. Thus, a bulk of our testing for units roots indicates that $\mathrm{CO}_{2}$ emissions, GDP, and electricity access variables are integrated in order 1 , but energy aid variables are stationary at levels $(I(0)$ variables). Due to the presence of $I(1)$ and $I(0)$ variables, the application of traditional cointegration tests such as Pedroni (2004), Kao (1999) and Bai and Ng (2002) are not justified. Therefore, we are justified in employing a PMG estimation to test for the existence of possible long-run relationships. ${ }^{11}$

Table 2 presents the estimation results of long-run relationships for two models with a $\log$ of per capita $\mathrm{CO}_{2}$ emissions as the dependent variable (Eq. 3, above). Each model includes the log of the per capita GDP variable, total electricity access

\footnotetext{
11 PMG estimation allows the estimation of short and long-run relationships for variables with mixed order of integration $I(0)$ and $I(1)$ if neither of variables has the order of integration higher than 1 and all our dependent variables such as $\mathrm{CO}_{2}, \mathrm{GDP}, \mathrm{EA}^{\mathrm{T}}, \mathrm{EA}^{\mathrm{R}}$ and $\mathrm{EA}^{\mathrm{U}}$ are $I(1)$ variables.
} 


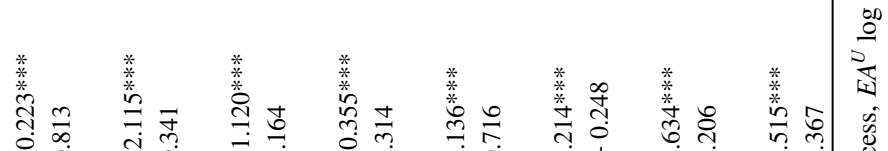

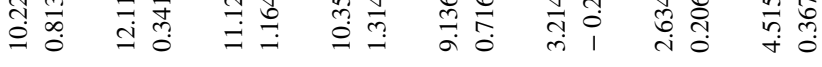

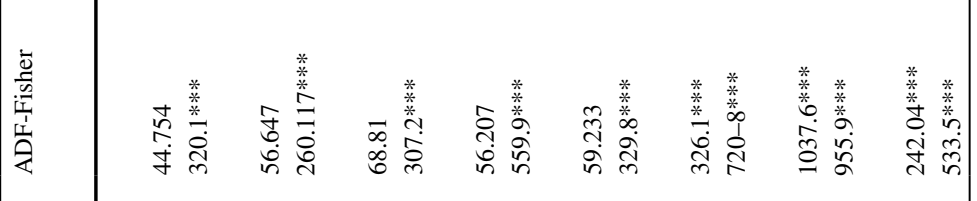

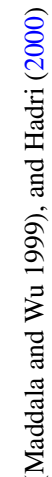

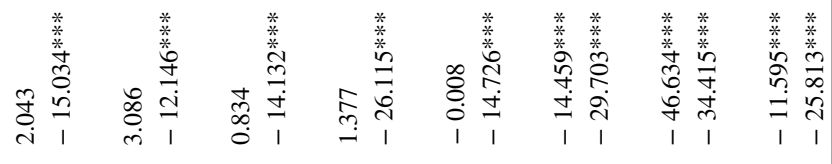

至

简

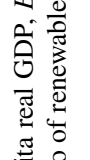

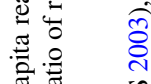

牙迹

气

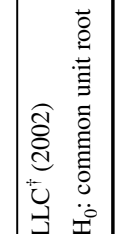

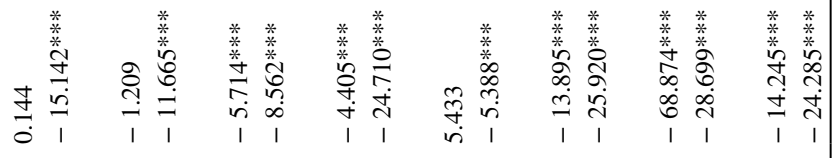



文

表

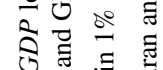

言苛

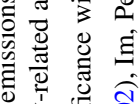

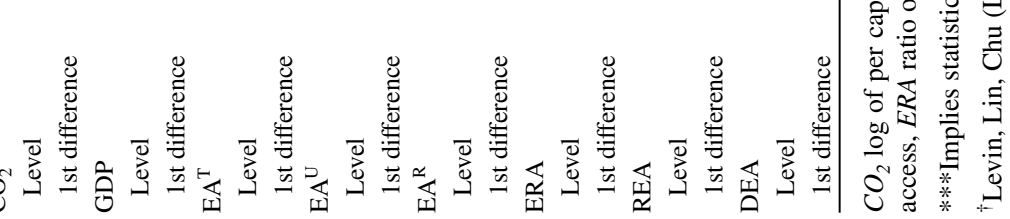

望 
Table 2 PMG estimation results for long-run and shortrun relationships Dependent Variable: $\mathrm{CO}_{2}$ emissions

\begin{tabular}{|c|c|c|c|c|}
\hline \multirow[t]{2}{*}{$\mathrm{CO}_{2}$} & \multicolumn{2}{|l|}{$\mathrm{CO}_{2-1}$} & \multicolumn{2}{|l|}{$\mathrm{CO}_{2-2}$} \\
\hline & Long-run & Short-run & Long-run & Short-run \\
\hline GDP & $\begin{array}{l}1.081 * * * \\
(0.077)\end{array}$ & $\begin{array}{l}0.510 * \\
(0.280)\end{array}$ & $\begin{array}{l}1.060 * * * \\
(0.076)\end{array}$ & $\begin{array}{l}0.564 * * \\
(0.268)\end{array}$ \\
\hline $\mathrm{EA}^{\mathrm{T}}$ & $\begin{array}{l}0.026 \\
(0.030)\end{array}$ & $\begin{array}{l}-0.071 \\
(0.046)\end{array}$ & $\begin{array}{l}0.012 \\
(0.023)\end{array}$ & $\begin{array}{l}-0.094 \\
(0.057)\end{array}$ \\
\hline ERA & $\begin{array}{l}-0.125^{* * * *} \\
(0.036)\end{array}$ & $\begin{array}{l}0.430^{*} \\
(0.255)\end{array}$ & - & - \\
\hline REA & - & - & $\begin{array}{l}-0.301^{* *} \\
(0.114)\end{array}$ & $\begin{array}{l}-53.698 \\
(61.668)\end{array}$ \\
\hline EDA & - & - & $\begin{array}{l}-0.336^{* * * *} \\
(0.078)\end{array}$ & $\begin{array}{l}21.775 \\
(21.652)\end{array}$ \\
\hline ECT & $\begin{array}{l}-0.271^{* * * *} \\
(0.047)\end{array}$ & - & $\begin{array}{l}-0.252 * * * \\
(0.042)\end{array}$ & - \\
\hline Constant & - & $\begin{array}{l}-0.501^{* * *} \\
(0.113)\end{array}$ & - & $\begin{array}{l}-0.423 * * * \\
(0.079)\end{array}$ \\
\hline
\end{tabular}

$\mathrm{CO}_{2} \log$ of per capita $\mathrm{CO}_{2}$ emissions, GDP log of per capita real GDP, $E A^{T} \log$ of total electricity access (\% of total population), ERA energy-related aid, $R E A$ renewable energy aid, EDA energy distribution aid

$*, * *, * * *$ Statistical significance within $10 \%, 5 \%$ and $1 \%$, respectively. Standard errors in parentheses

variable (EAT) and energy aid variable (ERA or REA and EDA). Specifically, both models $\mathrm{CO}_{2} \_1$ and $\mathrm{CO}_{2} 2$ estimate the impact of per capita GDP and total electricity access on $\mathrm{CO}_{2}$ emissions. However, model $\mathrm{CO}_{2-} 1$ uses total energyrelated aid (ERA) as an $A I D$ variable, while $\mathrm{CO}_{2} \_$uses both renewable energy aid (REA) and energy distribution aid (EDA) as relevant Aid variables.

As displayed in Table 2, the error correction terms are negative and statistically significant at $1 \%$ level in both specifications. These results indicate that the process converges to a long-term equilibrium. The coefficients for all AID variables are negative and statistically significant for both models. This suggests that in general energy-related aid as well as aid targeted to renewable energy and energy distribution can mitigate carbon emissions in the long run for SSA lowincome countries. These results are in line with Ikegami and Wang (2021), who note that energy aid reduces $\mathrm{CO}_{2}$ intensities in developing countries. About a fifth of the SSA's electricity comes from hydropower and more than $70 \%$ is from fossil fuels (Cartwright 2015). Moreover, Africa's electricity grid is quite unreliable, and therefore many African cities rely on expensive and 'dirty' diesel generators to make up shortfalls required for critical water purification, effluent treatment and event management. A reliable electricity supply provided though energyrelated aid, can potentially reduce dependence on backup diesel generators which can lead to reduction of $\mathrm{CO}_{2}$ emissions. In addition, new energy projects financed by energy-related aid probably are more energy efficient and environmentally friendly relative to existing power plants. Finally, increased electricity access in urban areas and the substitution of expensive diesel generators by solar PV would 
Table 3 PMG estimation results for long-run and shortrun relationships Dependent Variable: Per capita GDP

\begin{tabular}{|c|c|c|c|c|}
\hline \multirow[t]{2}{*}{ GDP } & \multicolumn{2}{|l|}{ GDP_1 } & \multicolumn{2}{|l|}{ GDP_2 } \\
\hline & Long-run & Short-run & Long-run & Short-run \\
\hline $\mathrm{CO}_{2}$ & $\begin{array}{l}0.735 * * * \\
(0.089)\end{array}$ & $\begin{array}{l}0.099 * * * \\
(0.043)\end{array}$ & $\begin{array}{l}0.777 * * * \\
(0.080)\end{array}$ & $\begin{array}{l}0.111 * * \\
(0.045)\end{array}$ \\
\hline $\mathrm{EA}^{\mathrm{T}}$ & $\begin{array}{l}0.392 * * * \\
(0.045)\end{array}$ & $\begin{array}{l}0.024 \\
(0.041)\end{array}$ & $\begin{array}{l}0.387 * * * \\
(0.043)\end{array}$ & $\begin{array}{l}0.023 \\
(0.053)\end{array}$ \\
\hline ERA & $\begin{array}{l}0.175 * * * \\
(0.076)\end{array}$ & $\begin{array}{l}0.177 \\
(0.147)\end{array}$ & - & - \\
\hline REA & - & - & $\begin{array}{l}0.566 * * * \\
(0.150)\end{array}$ & $\begin{array}{l}-13.490 \\
(21.787)\end{array}$ \\
\hline EDA & - & - & $\begin{array}{l}0.368 * * * \\
(0.113)\end{array}$ & $\begin{array}{l}1.115 \\
(1.525)\end{array}$ \\
\hline ECT & $\begin{array}{l}-0.053 * * \\
(0.014)\end{array}$ & - & $\begin{array}{l}-0.063 * * \\
(0.015)\end{array}$ & \\
\hline Constant & - & $\begin{array}{l}0.108 * \\
(0.057)\end{array}$ & - & $\begin{array}{l}0.114 * \\
(0.058)\end{array}$ \\
\hline
\end{tabular}

$\mathrm{CO}_{2} \log$ of per capita $\mathrm{CO}_{2}$ emissions, GDP log of per capita real GDP, $E A^{T} \log$ of total electricity access (\% of total population), $E R A$ energy-related aid, $R E A$ renewable energy aid, EDA energy distribution aid

$*, * *, * * *$ Statistical significance within $10 \%, 5 \%$ and $1 \%$, respectively. Standard errors in parentheses

reduce consumption of kerosene and biomass for lighting and cooking and thus help mitigate $\mathrm{CO}_{2}$ emissions. According to Lighting Africa (2010), the burning of kerosene emits between 30 and 50 million tonnes of $\mathrm{CO}_{2}$ in the continent.

In the short run, ERA is associated with increased $\mathrm{CO}_{2}$ emissions as the coefficient is positive and statistically significant, while coefficients for REA and EDA are found to be statistically insignificant. These results suggest that SSA low-income countries are more focused on conventional energy projects in the short run. These countries might use energy-related aid to operate currently installed energy plants, which are not very efficient and environmentally friendly and that in turn can lead to increased $\mathrm{CO}_{2}$ emissions.

Table 2 also reveals a positive and significant relationship from GDP to $\mathrm{CO}_{2}$ emissions in both the short- and the long-term. As GDP and $\mathrm{CO}_{2}$ variables were transformed into natural logarithms, their estimated parameters represent elasticities and suggest that a 1 percentage point increase in GDP growth increases $\mathrm{CO}_{2}$ emissions by about $1 \%$ in the long run and $0.5 \%$ over the short-term. These are per expectation, as an increase in GDP is usually associated with higher carbon emissions. Finally, the Table indicates that electricity access has no significant impact on $\mathrm{CO}_{2}$ emissions, a result that resonates with Tait and Winkler (2012) and Chakravarty and Tavoni (2013). For the short-run estimations electricity access coefficients are negative but not significant.

The PMG estimations on the short- and long-run elasticities for per capita GDP are displayed in Table 3. The negative and significant error correction terms in GDP equations in both specifications suggest the existence of long-run relationship among 
Table 4 PMG estimation results for long-run and shortrun relationships Dependent Variable: Total Electricity Access

\begin{tabular}{|c|c|c|c|c|}
\hline \multirow[t]{2}{*}{$\mathrm{EA}^{\mathrm{T}}$} & \multicolumn{2}{|l|}{$\mathrm{EA}^{\mathrm{T}}{ }_{-1}$} & \multicolumn{2}{|l|}{$\mathrm{EA}^{\mathrm{T}} \_2$} \\
\hline & Long-run & Short-run & Long-run & Short-run \\
\hline GDP & $\begin{array}{l}0.836 * * * \\
(0.058)\end{array}$ & $\begin{array}{l}0.083 \\
(0.294)\end{array}$ & $\begin{array}{l}0.826 * * * \\
(0.057)\end{array}$ & $\begin{array}{l}0.060 \\
(0.299)\end{array}$ \\
\hline ERA & $\begin{array}{l}0.029 \\
(0.067)\end{array}$ & $\begin{array}{l}-0.113 \\
(0.263)\end{array}$ & - & - \\
\hline REA & - & - & $\begin{array}{l}-0.083 \\
(0.138)\end{array}$ & $\begin{array}{l}-32.753 \\
(36.424)\end{array}$ \\
\hline EDA & - & - & $\begin{array}{l}0.207 \\
(0.163)\end{array}$ & $\begin{array}{l}1.938 \\
(1.907)\end{array}$ \\
\hline ECT & $\begin{array}{l}-0.295 * * * \\
(0.058)\end{array}$ & - & $\begin{array}{l}-0.275 * * * \\
(0.052)\end{array}$ & - \\
\hline Constant & - & $\begin{array}{l}-0.718 * * * \\
(0.161)\end{array}$ & - & $\begin{array}{l}-0.644 * * * \\
(0.140)\end{array}$ \\
\hline
\end{tabular}

$G D P \log$ of per capita real GDP, $E A^{T} \log$ of total electricity access (\% of total population), ERA energy-related aid, REA renewable energy aid, EDA energy distribution aid

$* * *$ Statistical significance within $1 \%$. Standard errors in parentheses

the variables. We estimated two specifications, GDP_1 and GDP_2, in a same manner as $\mathrm{CO}_{2-} 1$ and $\mathrm{CO}_{2}$ 2. Once again, the aid variables are of special interest to us as they can help us understand the role of aid on economic growth. In Table 3, the long-run coefficients for ERA, REA, and EDA are positive and statistically significant at $1 \%$ level. This suggests that all forms of aid facilitate economic development in low-income SSA countries in the long run. In the short-run energy aid related coefficients are not observed to be statistically significant. As mentioned above, SSA's electricity grid is notoriously unreliable, and on average an SSA firm suffers the loss of economic activities for about $77 \mathrm{~h}$ a month due to power outages. (Oseni and Pollitt 2013). Such electricity blackouts cost firms in the SSA region approximately $\$ 307$ per hour (Eberhard et al. 2011). A more reliable electricity grid can reduce such costs and in turn increase GDP. A recent report by the IEA (2021) highlights that the pandemic has resulted in 15 million people in SSA losing the ability to pay for electricity. The report also highlights that SSA receives only $15 \%$ of the annual investment required to achieve universal electricity access as visualized by SDG-7. Energy-related aid can increase the investment in the energy sector and create additional generation capacity to cover increasing electricity needs. Moreover, increasing capacity and reliable electricity grid might attract investment in industrial and service sectors that also can stimulate economic growth in the region.

Table 3 also indicates that an increase of $\mathrm{CO}_{2}$ emissions is positively associated with per capita GDP in short run as well as the long run, indicating that the countries within our sample are on the upward sloping portion of their inverted U-shaped EKCs. Finally, results in Table 3 demonstrate that total electricity access promotes economic growth in the long run within our sample of low-income SSA countries. The estimated coefficients for electricity access are positive and statistically 
significant at $1 \%$ level, but not in the short run, where the coefficients fail to achieve even $10 \%$ significance level. This result is in line with expectations that energy access can be an engine of economic growth (FAO 2000). Our findings also support the finding that the lack of access to energy in SSA has crimped its economic growth by 1-2\% (World Bank 2010).

The PMG estimations of long-run and short-run elasticities for total electricity access are displayed in Table 4. Within Table 4, specification $\mathrm{EA}^{\mathrm{T}}{ }_{-} 1$ considers per capita GDP and total energy-related aid (ERA) as the explanatory variables, while in $\mathrm{EA}^{\mathrm{T}} \_2$ model ERA variable is substituted by REA and EDA variables. The estimation results reveal the presence of long-run relationships in both equations as evidenced by the negative and significant error correction terms in both models. Table 4 indicates that the estimated coefficients for ERA REA and EDA are mostly positive, but not significant in the long run. This suggests that energy aid has no direct impact on the total electricity access in low-income SSA countries within our sample. These results are quite surprising as energy-related aid, especially renewable energy, is targeted toward increasing energy access in rural areas. There might be several possible reasons for this finding. Traditionally electricity in remote rural areas in SSA region has been reliant on expensive diesel generators. The reduction of levelized cost of electricity (LCOE) for renewable energy might have led to a substitution of diesel generators, with solar PV for example. In that case, people get more efficient and clean electricity, but that substitution does not affect rural electricity access. A second reason may lie in the inefficiencies associated with aid allocation itself. Finally, as mentioned above, there is a huge gap between required and current energy-related aid for SSA countries.

Table 4 also indicates that a higher GDP is associated with increased total electricity access in the long run. This result is in line with literature ${ }^{12}$ that has noted an association between higher per capita GDP and energy (electricity) consumption. The commensurate installation of new power plants to raise energy production can in turn improve access to electricity. In general, energy access projects require huge upfront investments in the SSA where effective demand may be low due to persistent poverty. A rise in incomes in the region may increase demand for energy and make electricity access projects more viable.

Finally, this paper compares the effects of per capita GDP and different types of energy-related aid on rural and urban electricity access. Table 5 shows the estimated results for four specifications, where the first two deal with rural electricity access $\left(\mathrm{EA}^{\mathrm{R}}{ }_{-} 1\right.$ and $\mathrm{EA}^{\mathrm{R}}{ }_{2}$ ) and the remaining two utilized estimations for urban electricity access as dependent variable $\left(\mathrm{EA}^{\mathrm{U}} \_1\right.$ and $\left.\mathrm{EA}^{\mathrm{U}} \_2\right)$. There is a long-term association among the variables as indicated by the negative and significant error correction term. Similar to the specifications that contained total electricity access as dependent variable, in models with rural and urban electricity access, increases in per capita GDP are correlated with an increase in electricity access in rural and urban areas in the long run. Table 5 also indicates that the impact of per capita GDP

\footnotetext{
12 Huang et al. (2008), has provided an excellent review of previous literature on the relationship between GDP growth and energy consumption.
} 


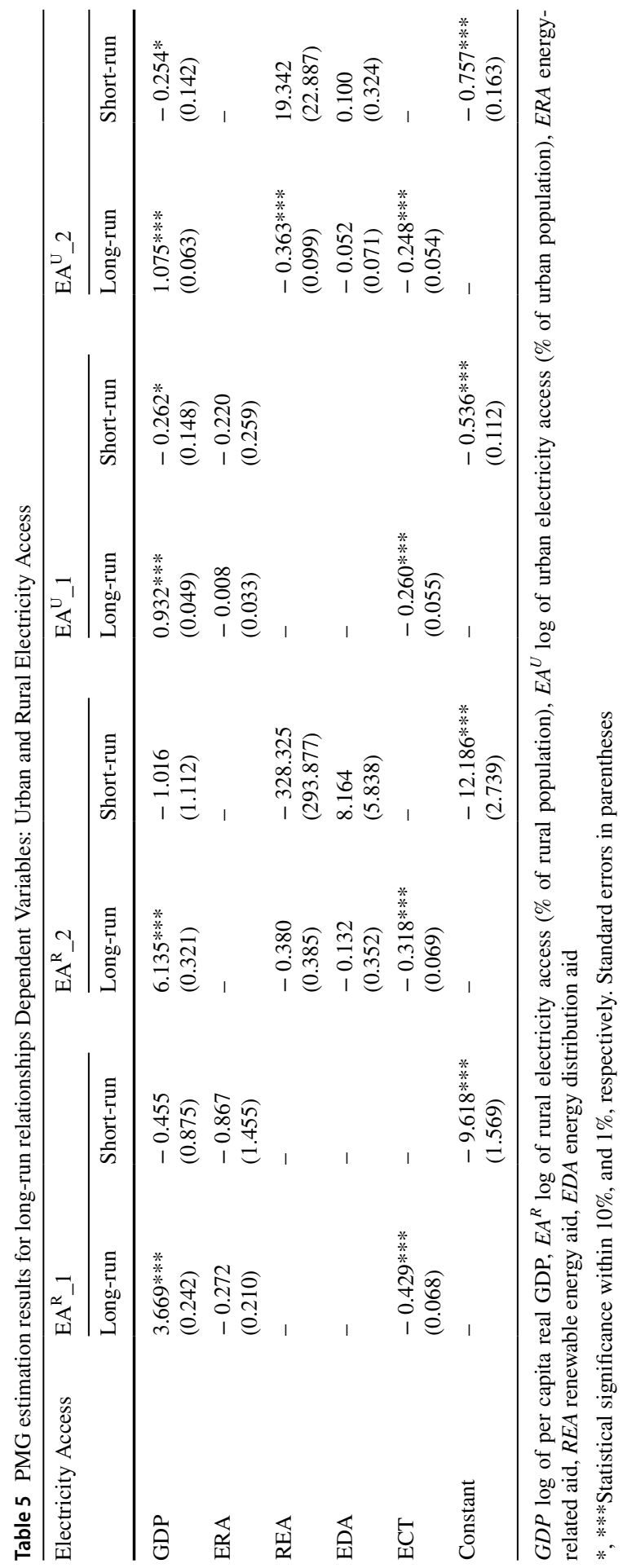


Fig. 5 Visual summary of results

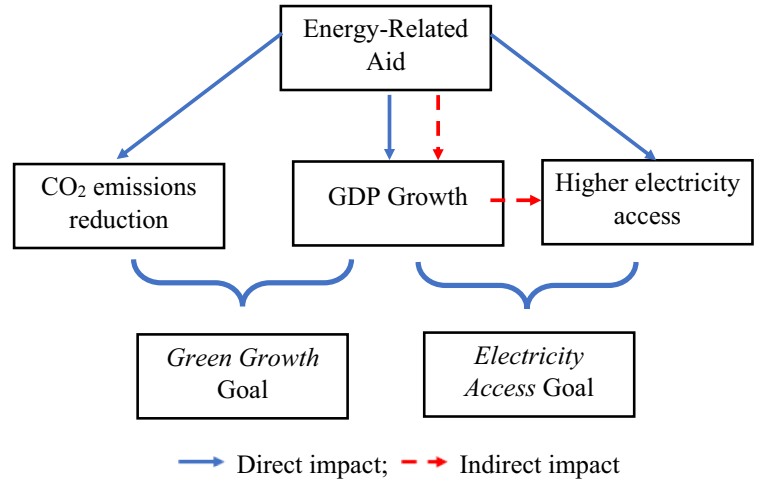

on rural electricity (3.67 and 6.13 for $\mathrm{EA}^{\mathrm{R}}{ }_{-} 1$ and $\mathrm{EA}^{\mathrm{R}}{ }_{2} 2$ models, respectively) is greater than its impact on urban electricity access $\left(0.932\right.$ and 1.075 for $\mathrm{EA}^{\mathrm{U}}{ }_{-} 1$ and $\mathrm{EA}^{\mathrm{U}}$ _2 models, respectively). Lastly, energy aid coefficients in all models are statistically insignificant, except for the negative long-run coefficient for REA (in the EA ${ }^{\mathrm{U}}$ model).

In sum, our results suggest that energy-related aid can mitigate $\mathrm{CO}_{2}$ emissions as well as promote per capita GDP in our sample of low-income SSA countries. However, energy-related aid does not directly contribute to total, rural and urban electricity access. Long-run estimates also indicate that an increase in GDP and electricity access are positively associated, suggesting an indirect relationship between energy aid and electricity access, mediated by higher economic growth. These results are in line with the findings of Poloamina and Umoh (2003) and Sarkodie and Adams (2020) who note a positive association between per capita GDP and electricity access in SSA countries. Finally, the positive association between GDP and CO2 emissions noted in our results imply that the low-income SSA countries in our sample are still in the upward sloping parts of their inverted U-shaped EKCs.

\section{Conclusion and Implications}

This paper examines how energy-related aid impacts carbon emissions, economic growth, and electricity access for a sample of low-income SSA countries from 1995 to 2016. A novelty of our analysis is that it explicitly considers electricity access as an explanatory variable, in contrast to other studies that mostly employ energy production or electricity consumption as determinants.

The paper's econometric investigation centered around three research questions. First, the analysis considered whether increased energy aid was associated with mitigated carbon emissions. Our econometric results indicated a positive association between energy-related aid and reduced carbon emissions. The second research question was concerned with the link between energy-related aid and economic growth. Our results noted that energy-related aid is associated with higher economic growth for our sample of low-income SSA countries. The final research question 
asked if energy-related aid improved access to energy? Our empirical investigation suggests that energy-related aid is not directly associated with improved electricity access in low-income SSA countries. However, results also indicate a positive longrun association between economic growth and electricity access which is indicative of an indirect relationship between energy-related aid and electricity access. Figure 5 provides a visual summary.

Our econometric findings offer some implications for policy. While greater energy-related aid can facilitate economic growth in low-income Sub-Saharan African countries, it cannot assure electricity access in such countries. Thus, our results support policies that underscore the relevance of a green growth trajectory but not an energy access trajectory as distinguished by Bruggink (2012). However, out findings also indicate that energy-related aid can impel economic growth which in turn can promote greater access to electricity. Increasing energy-related aid to the SSA region can help improve access to affordable, reliable, sustainable and modern energy for all by 2030 - an objective consecrated in the UN Sustainable Development Goal 7 (SDG-7).

In a recent study the World Energy Outlook (2020) noted that as a direct result of the pandemic, the number of people in Africa without access to electricity had risen to more than 590 million in 2020, which is an almost 2\% increase from 2019. In addition to the obvious resource constraints on governments, even private companies have faced operational and financial difficulties in providing electricity to unserved populations in the SSA region. The pandemic has merely amplified ongoing constraints and literally reversed years of progress that the region had been making toward increasing access to electricity. From a policy perspective, this suggests that improvements in energy access will require increased investment and engagement on part of donor countries and development finance institutions. According to the IEA (2020a, b), achieving the goals of SDG-7 will require around \$20 billion of annual energy-related investments from 2021 to 2030. These investments would go to decentralized electricity systems as well as centralized power generation, distribution and transmission. The results of our analysis underscore that it is imperative for governments and donors to prioritize electricity access in the SSA region by ensuring financial support and the provision of energy-related aid. In this context, mobilizing development finance institutions and donors is critical to ensure sustainable progress toward SDG-7.

A limitation of our study as mentioned above is the choice of time period that was constrained by access to data. However, this limitation opens several possibilities for future research on energy access and economic growth in SSA especially in the context of the pandemic and progress toward meeting the goals of SDG-7. A recent report by the IEA (2021) indicates that the pandemic has had the most detrimental effect on progress toward SDG-7 in the SSA region. Almost 4 out of 5 people in the region do not have access to electricity. Achieving the objectives of SDG-7 by 2030 will require expenditures of nearly USD 43 billion a year and recent data suggests that the SSA region is trailing in terms of investment funding. The region receives a paltry $15 \%$ of the investment required to achieve the universal electricity access objectives of SDG-7. The urgency of the situation is evident and deserving of research as well as funding. As more data, especially on carbon emissions becomes 
available, researchers will be able to examine the role of energy aid in the growth stories of the SSA countries as well as their progress in meeting SDG goals. Further, as of 2020, many countries in the SSA region have yet to establish electricity access targets. The lack of strong regulatory frameworks can have consequences on their access to investment funding. Setting up specific national plans for achieving SDG goals and climate mitigation strategies can be a necessary first step toward balancing energy access, economic growth needs, and mitigating carbon emissions in the SSA.

Despite the topicality of electricity access in the SSA, regional cooperation around the issue has not received adequate scholarly attention. As suggested by Taghizadeh-Hesary et al. (2021) for the Asia-Pacific region, the concept of intraregional cooperation on renewable energy may also be worth investigating for the SSA region. Indeed, Nalule (2019) has noted that SSA countries have shared energy common energy concerns which could be addressed by collective efforts through regional cooperation. The author argues that grid-tied electricity infrastructures such as the West African Power Pool (WAPP), East African Power Pool (EAPP), and the Southern African Power Pool (SAPP) can offer templates for regional cooperation toward achieving access to modern energy in the region. Effective regional energy integration strategies in the SSA can help achieve access to energy as well as unleash positive multiplier effects on economic development, political trust, environmental sustainability, and transfer of technology among countries within the region. Consequently, there is a need to put mechanisms and structures in place to engender renewable energy development in the region. In this context, SSA energy policy makers can refer to a playbook of strategies proposed by Sarker et al. (2020) for South Asia that proposes multiple models for augmenting regional cooperation for sharing knowhow, finances, and physical resources in the energy sector.

Table 6 Descriptive statistics and data sources

\begin{tabular}{|c|c|c|c|c|}
\hline Variable & Mean & Min & Max & Data source \\
\hline $\begin{array}{l}\mathrm{CO}_{2} \text { emissions } \\
\text { (kg per capita) }\end{array}$ & 268.65 & 16.279 & 1664.7 & \multirow{5}{*}{$\begin{array}{l}\text { The World Bank, World Development } \\
\text { Indicators } \\
\text { http://databank.worldbank.org/data/repor } \\
\text { ts.aspx?source=world-development- } \\
\text { indicators\# }\end{array}$} \\
\hline $\begin{array}{l}\text { GDP } \\
\text { (constant } 2010 \text { US\$ per capita) }\end{array}$ & 866.11 & 183.55 & 3843.2 & \\
\hline $\begin{array}{l}\text { Electricity access (total) } \\
\text { (\% of total population) }\end{array}$ & 21.31 & 0.01 & 79.931 & \\
\hline $\begin{array}{l}\text { Electricity access (rural) } \\
\text { (\% of rural population) }\end{array}$ & 8.466 & 0.01 & 79.273 & \\
\hline $\begin{array}{l}\text { Electricity access (urban) } \\
\text { (\% of population) }\end{array}$ & 52.66 & 5.494 & 91.983 & \\
\hline $\begin{array}{l}\text { Total energy aid } \\
\text { (ratio to GDP) }\end{array}$ & 0.125 & 0 & 3.859 & \multirow{3}{*}{$\begin{array}{l}\text { Creditor Reporting System } \\
\text { http://stats.oecd.org/Index.aspx?DataS } \\
\text { etCode=CRS1 }\end{array}$} \\
\hline $\begin{array}{l}\text { Renewable energy aid } \\
\text { (ratio to GDP) }\end{array}$ & 0.0413 & 0 & 2.304 & \\
\hline $\begin{array}{l}\text { Energy distribution aid } \\
\text { (ratio to GDP) }\end{array}$ & 0.0576 & 0 & 3.094 & \\
\hline
\end{tabular}




\section{Appendix}

\section{See Tables 6 and 7.}

Table 7 Country list

\begin{tabular}{lll}
\hline Angola & Gambia, The & Niger \\
Benin & Ghana & Nigeria \\
Burkina Faso & Guinea & Rwanda \\
Burundi & Guinea-Bissau & Sierra Leone \\
Central African Republic & Kenya & Sudan \\
Chad & Lesotho & Tanzania \\
Congo, Dem. Rep & Madagascar & Togo \\
Congo, Rep & Malawi & Uganda \\
Eritrea & Mali & Zambia \\
Ethiopia & Mozambique & Zimbabwe \\
\hline
\end{tabular}

\section{References}

Alam, M.M., M.W. Murad, A.H.M. Noman, and I. Ozturk. 2016. Relationships among carbon emissions, economic growth, energy consumption and population growth: Testing Environmental Kuznets Curve hypothesis for Brazil, China, India and Indonesia. Ecological Indicators 70: 466-479. https:// doi.org/10.1016/j.ecolind.2016.06.043.

Alshehry, A.S., and M. Belloumi. 2015. Energy consumption, carbon dioxide emissions and economic growth: The case of Saudi Arabia. Renewable Sustainable Energy Rev. 41: 237-247. https://doi.org/ 10.1016/j.rser.2014.08.004.

Altinay, G., and E. Karagol. 2005. Electricity consumption and economic growth: Evidence from Turkey. Energy Economics 27 (6): 849-856. https://doi.org/10.1016/j.eneco.2005.07.002.

Al-Mamun, M. 2013. The effect of macroeconomic \& market specific dynamics on stock market development in global growth generator countries. Asian Economic and Financial Review, Asian Economic and Social Society 3 (9): 1152-1169.

Arvin, B.M., P. Dabir-Alai, and B. Lew. 2006. Does foreign aid affect the environment in developing economies? Journal of Economic Development 31 (1): 63-87.

Arvin, B.M., and B. Lew. 2009. Foreign aid and ecological outcomes in poorer countries: An empirical analysis. Applied Economics Letters 16 (3): 295-299. https://doi.org/10.1080/13504850601018312.

Asumadu-Sarkodie, S., and P.A. Owusu. 2016. The relationship between carbon dioxide and agriculture in Ghana: A comparison of VECM and ARDL model. Environmental Science and Pollution Research 23 (11): 10968-10982.

Bai and $\mathrm{Ng}$. 2002. Determining the number of factors in approximate factor models. Econometrica 70 : 191-221. https://doi.org/10.1111/1468-0262.00273.

Balisacan, A.M. 2001. Pathways of poverty reduction: Rural development and transmissions mechanisms in the Philippines. Working paper: Asia and Pacific Forum on Poverty: Reforming Policies and Institutions for Policy Reductions. Manila, 5-9 February. http://citeseerx.ist.psu.edu/viewdoc/downl oad?doi=10.1.1.200.7080\&rep=rep1\&type=pdf.

Baltagi, B.H. 2005. Econometric analysis of panel data, 3rd ed. New York: Wiley.

Barnes, D.F., and H.P. Binswanger. 1986. Impact of rural electrification and infrastructure on agricultural changes, 1960-1980. Economic and Political Weekly 21 (1): 26-34.

Bayar, Y., and H.A. Özel. 2014. Electricity consumption and economic growth in emerging economies. Journal of Knowledge Management, Economics and Information Technology 4 (2): 1-18.

Bekhet, H.A., A. Matar, and T. Yasmin. 2017. $\mathrm{CO}_{2}$ emissions, energy consumption, economic growth, and financial development in GCC countries: Dynamic simultaneous equation models. Renewable and Sustainable Energy Reviews 70: 117-132. https://doi.org/10.1016/j.rser.2016.11.089. 
Bednar-Friedl, Birgit and Michael. Getzner. 2003. Determinants of $\mathrm{CO}_{2}$ emissions in a small open economy. Ecological Economics 45: 133-148. https://doi.org/10.1016/S0921-8009(03)00008-9.

Bhattacharyya S., M. Intartaglia, and A. McKay. 2016. Does climate aid affect emissions? Evidence from a global dataset. Working paper Centre for the Study of African Economies (CSAE), Falmer. http:// www.sussex.ac.uk/economics/documents/wps-94-2016.pdf.

Bruggink, J. 2012. Energy aid in times of climate change. Energy Research Centre of the Netherlands.

Burnside, C., and D. Dollar. 1997. Aid, policies, and growth. Policy Research Working Paper No. 1777, World Bank, Washington DC.

CAIT Climate Data Explorer. n.d. http://cait.wri.org/.

Cartwright, A. 2015. Better growth, better cities: Rethinking and redirecting urbanisation in Africa. Working Paper. London and Washington: New Climate Economy.

Chakravarty, S., and M. Tavoni. 2013. Energy poverty alleviation and climate change mitigation: Is there a trade-off? Energy Econ 40 (Suppl. 1): 567-573.

Chao, C.C., and E.S.H. Yu. 1999. Foreign aid, the environment, and welfare. Journal of Development Economics 59 (2): 553-564.

Chen, J.H., and Y.F. Huang. 2013. The study of the relationship between carbon dioxide $\left(\mathrm{CO}_{2}\right)$ emission and economic growth. Journal of International and Global Economic Studies 6: 45-61.

Chiu, Y.-B. 2017. Carbon dioxide, income and energy: Evidence from a non-linear model. Energy Economics 61: 279-288. https://doi.org/10.1016/j.eneco.2016.11.022.

Chow, G.C., and J. Li. 2014. Environmental Kuznets Curve: Conclusive econometric evidence for $\mathrm{CO}_{2}$. Pacific Economic Review 19 (1): 1-7. https://doi.org/10.1111/1468-0106.12048.

Collier, P., and D. Dollar. 2001. Can the world cut poverty in half? How policy reform and effective aid can meet international development goals. World Development 29 (11): 787-802.

Collier, P., and D. Dollar. 2002. Aid allocation and poverty reduction. European Economic Review 46 (8): 1475-1500.

Dalgaard, C.J., and H. Hansen. 2001. On aid, growth and good policies. Journal of Development Studies 37 (6): $17-41$.

Dinda, S., and D. Coondoo. 2006. Income and emissions: A panel based cointegration analysis. Ecological Economics 57 (2): 167-181.

Dinkelman, T. 2008. The effects of rural electrification on employment: New evidence from South Africa. Mimeo: University of Michigan.

Eberhard, A., O. Rosnes, M. Shkaratan, and H. Venn. 2011. Africa's Power Infrastructure: Investment, integration, efficiency. Washington DC: World Bank Paper, 61390. https://openknowledge.world bank.org/bitstream/handle/10986/2290/613090PUB0Afri158344B09780821384558.pdf?seque nce $=1$.

Escribano, A., J.L. Guasch, and J. Pena. 2009. Assessing the impact of infrastructure quality on firm productivity in Africa. Working Paper 9, Africa Infrastructure Sector Diagnostic, World Bank. Washington D.C. https://core.ac.uk/.

ESMAP_Energy Sector Management Assistance Program. 2005. Study to promote productive uses of electricity in rural electrification projects in Tanzania. DataVision International Ltd.

Esteve, Vicente, and Cecilio Tamarit. 2012. Threshold cointegration and nonlinear adjustment between $\mathrm{CO}_{2}$ and income: The Environmental Kuznets Curve in Spain, 1857-2007. Energy Economics 34 (6): 2148-2156.

Fan, S., P. Hazell, and S. Thorat. 2000. Government spending, growth, and poverty in rural India. American Journal of Agricultural Economics 82 (4): 1038-1051.

Fan S., D. Nyange, and N. Rao. 2005. Public investment and poverty reduction in Tanzania: Evidence from household survey data. International Food Policy Research Institute DSGD Discussion Paper 18. http://purl.umn.edu/58373.

Fan, S., L. Zhang, and X. Zhang. 2002. Growth, inequality, and poverty in rural China: The role of public investment. Research Report 125. International Food Policy Research Institute. Washington D.C. http://www.ifpri.org/publication/growth-inequality-and-poverty-rural-china-role-public-inves tments.

FAO. 2000. The Energy and Agriculture Nexus. Environment and Natural Resources Working Paper No. 4. FAO, Rome. http://www.fao.org/3/X8054E/X8054E00.htm.

FAOSTAT Emissions Database. FAOSTAT. n.d.. http://www.fao.org/faostat/en/\#data.

Fayad Gh. 2010. Remittances and Dutch disease: A dynamic heterogeneous panel analysis on the Middle East and North Africa region. Working Paper. Centre for the Study of African Economies, 
Department of Economics, University of Oxford, UK. http://citeseerx.ist.psu.edu/viewdoc/downl oad?doi=10.1.1.447.4941\&rep=rep1\&type=pdf.

Galeotti, Marzio, and Alessandro. Lanza, 1999. Richer and cleaner? A study on carbon dioxide emissions in developing countries. Energy Policy 27: 565-573.

Goedhuys, M., and L. Sleuwaegen. 2010. High-growth entrepreneurial firms in Africa: A quantile regression approach. Small Business Economics 34 (1): 31-51.

Grimm M., R. Hartwig, and J. Lay. 2011. How much does utility access matter for the performance of micro and small enterprises? http://www.iss.nl/fileadmin/ASSETS/iss/Documents/Research_and_ projects/Unlocking_potential_Utility_Access.pdf.

Grossman, G.M., and A.B. Krueger. 1991. Environmental impacts of a North American free trade agreement (NBER Working Paper No. 3914). Cambridge, MA: National bureau of economic research. https://journals.iupui.edu/index.php/iiclr/article/download/17486/17601.

Hadri, K. 2000. Testing for stationarity in heterogeneous panel data. Econometrics Journal 3: 148-161.

Hafner, M., L.D. Strasser, and S. Tagliapietra. 2018. Energy in Africa: Challenges and opportunities. New York: Springer.

Hansen, H., and F. Tarp. 2001. Aid and growth regressions. Journal of Development Economics 64 (2): 547-570.

Hatzipanayotou, P., S. Lahiri, and M.S. Michael. 2002. Can cross-border pollution reduce pollution? Canadian Journal of Economics 35 (4): 805-818.

Hossain, M.S. 2011. Panel estimation for $\mathrm{CO}_{2}$ emissions, energy consumption, economic growth, trade openness, and urbanization of newly industrialized countries. Journal of Energy Policy 39 (11): 6991-6999.

Hu, H., N. Xie, D. Fang, and X. Zhang. 2018. The role of renewable energy consumption and commercial services trade in carbon dioxide reduction: Evidence from 25 developing countries. Applied Energy 211: 1229-1244. https://doi.org/10.1016/japenergy.2017.12.019.

IEA. 2020a. The Covid-19 crisis is reversing progress on energy access in Africa. Paris: IEA.

IEA. 2020b. World Energy Outlook 2020. Paris: IEA.

IEA (International Energy Agency). 2021. World Energy Outlook 2021. Paris: IEA.

Ikegami, M., and Z. Wang. 2021. Does energy aid reduce $\mathrm{CO}_{2}$ emission intensities in developing countries? Journal of Environmental Economics and Policy. https://doi.org/10.1080/21606544.2021. 1882342.

Im, K.S., M.H. Pesaran, and Y. Shin. 2003. Testing for unit roots in heterogeneous panels. Journal of Econometrics 115 (1): 53-74.

Islam, M. 2002. Political regimes and the effect of foreign aid on economic growth. Journal of Developing Areas 37 (1): 35-53.

Jensen P.S., and M. Paldam. 2003. Can the new aid-growth models be replicated? Economics Working Papers, No.17, School of Economics and Management, University of Aarhus. https://doi.org/10. 1007/s11127-006-0865-4.

Kao, C. 1999. Spurious regression and residual-based tests for cointegration in panel data. Journal of Econometrics 90: 1-44.

Kooijman-van Dijk, A. 2008. The power to produce-the role of energy in poverty reduction through small scale enterprises in the Indian Himalayas. Enschede: University of Twente.

Kooijman-van Dijk, A. 2012. The role of energy in creating opportunities for income generation in the Indian Himalayas. Energy Policy 41: 529-536.

Kraft, J. and A. Kraft. 1978. On the Relationship between Energy and GNP. Journal of Energy Development 3: 401-403.

Lee, C.-C., and J.-D. Lee. 2009. Income and $\mathrm{CO}_{2}$ emissions: Evidence from panel unit root and cointegration tests. Energy Policy 37 (2): 413-423.

Legros, G., I. Havet, N. Bruce, and S. Bonjour. 2009. The Energy access situation in developing countries: A review focusing on the least developed countries and Sub-Saharan Africa. UNDP, and WHO.

Lensink, R., and H. White. 2001. Are there negative returns to aid? Journal of Development Studies 37 (6): 42-65.

Levin, A., C.-F. Lin, and C.-S.J. Chu. 2002. Unit root tests in panel data: Asymptotic and finite-sample properties. Journal of Econometrics 108: 1-24.

Lighting Africa. 2010. Solar Lighting for the Base of the Pyramid-Overview of an Emerging Market, IFC, World Bank Group. http://www.ifc.org/wps/wcm/connect/a68a120048fd175eb8dcbc84953783 2d/SolarLightingBasePyramid.pdf?MOD=AJPERES. 
Liobikienė, G., and M. Butkus. 2017. Environmental Kuznets curve of greenhouse gas emissions including technological progress and substitution effects. Energy 135: 237-248. https://doi.org/10.1016/j. energy.2017.06.120.

Lipford, J.W., and B. Yandle. 2010. Environmental Kuznets Curves, carbon emissions, and public choice. Environment and Development Economics 15: 417-438.

Maddala, G.S., and Wu. Shaowen. 1999. A comparative study of unit root tests with panel data and a new simple test. Oxford Bulletin of Economics and Statistics 61: 631-652.

Mahalik, M.K., M.A. Villanthenkodath, H. Mallick, and M. Gupta. 2021. Assessing the effectiveness of total foreign aid and foreign energy aid inflows on environmental quality in India. Energy Policy. https://doi.org/10.1016/j.enpol.2020.112015.

Marques, A.C., J.A. Fuinhas, and P.A. Leal. 2018. The impact of economic growth on CO2 emissions in Australia: The environmental Kuznets curve and the decoupling index. Environmental Science and Pollution Research 25 (27): 27283-27296. https://doi.org/10.1007/s11356-2768-6.

Martınez-Zarzoso, Inmaculada, Aurelia. Bengochea-Morancho. 2004. Pooled mean group estimation of an environmental Kuznets curve for $\mathrm{CO}_{2}$. Economics Letters 82 (1): 121-126

Mehdi, B.J., and B.S. Youssef. 2015. The Role of Renewable Energy Consumption and Trade: Environmental Kuznets Curve Analysis for Sub-Saharan Africa Countries. African Development Review 27: 288-300. https://doi.org/10.1111/1467-8268.12147.

Modi, V., S. McDade, D. Lallement, and J. Saghir. 2005. Energy services for the millennium development goals. New York: Energy Sector Management Assistance Programme (ESMAP), United Nations Development Programme (UNDP), UN Millennium Project, and World Bank.

Nalule, V. 2019. Energy poverty and access challenges in Sub-Saharan Africa: The role of regionalism. Switzerland: Palgrave Macmillan.

Narayan, P.K., S. Narayan, and A. Prasad. 2008. A structural VAR analysis of electricity consumption and real GDP: Evidence from the G7 countries. Energy Policy 36 (7): 2765-2769. https://doi.org/ 10.1016/j.enpol.2008.02.027.

Nazeer, M., U. Tabassum, and S. Alam. 2016. Environmental pollution and sustainable development in developing countries. The Pakistan Development Review 55: 589-604.

Odhiambo, N.M. 2012. Economic growth and carbon emissions in South Africa: An empirical investigation. Journal of Applied Business Resources 28 (1): 1-37.

OECD Statistics. n.d. http://stats.oecd.org.

Oseni M.O., and M.G. Pollitt. 2013. The economic costs of unsupplied electricity: Evidence from backup generation among African firms. Working Papers EPRG 1326, Energy Policy Research Group, Cambridge Judge Business School, University of Cambridge.

Ozturk, I. 2010. A literature survey on energy-growth nexus. Energy Policy 38 (1): 340-349.

Pedroni, P. 2004. Panel cointegration, asymptotic and finite sample properties of pooled time series tests with an application to the PPP hypothesis. Econometric Theory 20: 597-625.

Pesaran, M.H., Y. Shin, and R. Smith. 1999. Pooled mean group estimator of dynamic heterogeneous panels. Journal of the American Statistical Association 94 (44): 621-634.

Poloamina, I.D., and U.C. Umoh. 2013. The determinants of electricity access in Sub-Saharan Africa. The Empirical Econometrics and Quantitative Economics Letters, Faculty of Economics 2 (4): 65-74.

Ram, R. 2004. Recipient country's 'policies' and the effect of foreign aid on economic growth in developing countries: Additional evidence. Journal of International Development 16 (2): 201-211.

Salim, R.A., K. Hassan, and S. Shafiei. 2014. Renewable and non-renewable energy consumption and economic activities: Further Evidence from OECD countries. Energy Economics 44: 350-360.

Sarker, T., S. Hossain, and N. Islam. 2020. The role of regional cooperation and integration in resolving energy security in South Asia. In Energy Insecurity in Asia: Challenges, solutions, and renewable energy, ed. Yoshino et al. 109-139. Tokyo: Asian Development Bank Institute.

Sarkodie, S.A., and S. Adams. 2020. Electricity access, human development index, governance and income inequality in Sub-Saharan Africa. Energy Reports 6: 455-466.

Shafik, N. 1994. Economic Development and Environmental Quality: An Econometrics Analysis. Oxford Economic Papers 46: 757-773.

Srivastava, S.K. 2016. Causal relationship between electricity consumption and GDP: Plausible explanation on previously found inconsistent conclusions for India. Theoretical Economics Letters 6 (1): 276-281.

Taghizadeh-Hesary, F., T. Sarker, A. Mortha, and C.J. Kim. 2021. Energy security and economic integration: a comparative analysis of Europe and Asia-Pacific. In Economic integration in Asia and 
Europe: Lessons and policies, ed. S.C. Park, C.J. Kim, F. Taghizadeh-Hesary, and P. Sirivunnabood, 593-620. Japan: Asian Development Bank Institute.

Tait, Louise, and Harald Winkler. 2012. Estimating greenhouse gas emissions associated with achieving universal access to electricity for all households in South Africa. Journal of Energy in Southern Africa 23 (4): 8-17.

World Bank. 1998. Assessing aid: What works, what doesn't and why. New York: Oxford University Press.

World Bank. 2001. The World Bank group's energy program poverty reduction, sustainability and selectivity. Energy and mining sector board. http://documents1.worldbank.org/curated/en/2476614681 54471211/pdf/760730WP0Energ00Box374334B00PUBLIC0.pdf.

World Bank. 2010. Africa's infrastructure-a time for transformation. Vivien Foster and Cecilia Briceno-Garmendia (ed.), to be published, Washington: Agence Francaise de Dévelopement and the World Bank.

World Bank. 2019. More people have access to electricity than ever before, but world is falling short of sustainable energy goals. Press Release No: 2019/176/ENERGY. https://www.worldbank.org/en/ news/press-release/2019/05/22/tracking-sdg7-the-energy-progress-report-2019.

World Development Indicators. 2021. https://databank.worldbank.org/source/world-development-indic ators.

Publisher's Note Springer Nature remains neutral with regard to jurisdictional claims in published maps and institutional affiliations. 